\title{
EVALUATION OF HOUSEHOLD FOOD WASTE AS SHEEP FEED
}

\author{
Eldsokey E. N., Elsayed M. H., Abdelnasser A. B.
}

Nutrition and Clinical Nutrition Department, Faculty of Veterinary Medicine, Kafrelsheikh University, Egypt

\begin{abstract}
The objectives of this study were to determine nutrient composition of household food waste (HFW) and to investigate its effects on lamb growth performance, digestibility and carcass characteristics. HFW was collected, sun dried, ground, and chemically analyzed. After drying, it was tested as an ingredient in formulating a balanced ration for lambs in different levels (0,15 and 30\%) on as-fed basis. Fifteen male lambs, with an average body weight $22.98 \mathrm{~kg}$, were allotted randomly into three groups (5 each) and fed ad libitum for 8 weeks. $H F W$ was found to be relatively high in protein (14.72\%), ether extract (6.96\%), non fibrous carbohydrate (47.39\%), and ash (10.98\%). Analysis of HFW revealed that it was free from total aflatoxins. Lambs fed 15 and 30\% HFW-diets performed as those fed the control diet in growth and feed efficiency. Digestibility of ether extract was better for diets containing HFW than that of the control diet. There were no significant effects of HFW on fasted live weight, carcass weight and dressing percentages. The income over feed cost indicated that the income on diet based 30\% HFW was higher than that of the control one. As a conclusion HFW could be used as a lowcost feed in lamb diets without any adverse effect on performance or carcass characteristics. Further studies on methods of HFW processing and value for other species are suggested.
\end{abstract}

Key words: Sheep, Household food waste, Growth performance, Digestibility. 


\section{INTRODUCTION}

While large amount of nutrients accumulate in Egypt as household food waste $(\mathrm{HFW})$, livestock are suffering from malnutrition, expensive feedstuffs, and poor balanced feed supply which make the livestock sector unsustainable. Food waste (FW) includes vegetable, fruit, animal by-products and cereals wastes. Data on the amount of FW are relatively sparse, and vary from $20 \%$ to $40 \%$ of purchased food, depending on what is being measured. A recent estimate depending on energy calculations indicated that the rate of waste exceeds $40 \%$ in United States (Hall et al., 2009). It was reported that the amount of FW in Japan is twenty million tons per year, of which the amount used as a fertilizer and a feed were 3 and 5\%, respectively (Kawashima, 2004). Up till now, there was no statistical data about the amount of FW in Egypt.

The current trend towards FW recycling is motivated by both economic and environmental consideration. Since feed costs are about $80 \%$ of the total animal production costs (Boucque and Fiems, 1988), the substitution of conventional feedstuffs by processed FW could resulted in a significant reduction in the costs of animal feed and the ultimate derived products. The objective behind recycling FW into animal product is to achieve the same level of performance while decreasing the cost of production and attaining a more sustainable agriculture system (Normand, 1997).

These FW usually has high energy and/or protein contents, which could provide competitive alternatives to more traditional energy or protein sources (Westendorf, 2000). Replacing imported commercial 
feeds with FW can save energy in transportation and reduce the environmental impact of burning or land filling FW (Cao et al., 2009). FW had high nutritive value and can be used in sheep feeding with no problem (Summers et al., 1980). Therefore, the purpose of this study was determination the amount of FW per person per day in Egypt determination the chemical composition of HFW to investigate its effects on lamb growth performance, nutrient digestibility, carcass characteristics and meat chemical composition. This study will reveal economic effects of FW recycling as a sheep feed in Egypt.

\section{MATERIALS AND METHODS}

\section{Collection, quantification and processing of HFW:}

From January to March 2010, the economic, public health and environmental effects of HFW recycling were explained and discussed with employees, students, our faculty members, restaurant staff of Kafrelsheikh University and number of families in Kafrelsheikh city to cooperate in separation and collection of HFW. Plastic bags of different colors (green and black) were offered to coordinators to separate and collect HFW in green bags and discard other wastes in black bags. From February to May 2010, the HFW was daily collected, physically evaluated to discard forgotten plastics, metals and glasses. HFW was freshly weighed and the number of coordinators was recorded to determine the amount of HFW per person per day. HFW was dried using direct sun light for 5-7 days depending on ambient temperature. It was spread in thin layers and turned daily to facilitate drying and to avoid 
growth of mold or decomposition. Moisture content was determined periodically till reached $12 \%$. The dried HFW was collected and stored in bags in cool dry place. Air dried HFW was ground mixed and sampled for chemical analysis and total aflatoxins determination.

\section{Animals and diets:}

The trial was carried out on 15 male lambs, weighed an average $22.98 \mathrm{~kg}$ and divided into three groups (0\% HFW, 15\% HFW and 30\% HFW) of 5 animals each, homogeneous for age and litter size. The animals were placed in individual straw-bedded pens and underwent a fattening period of 8 weeks preceded by an adaptation period of 10 days. During the adaptation period, the lambs were treated for internal parasites. Procedures were conducted according to the guidelines of the Council Directive 86/609/EEC (European Communities, 1986) on the protection of animals used for experimental and other scientific purposes.

One basal control diet was formulated from alfalfa hay, Egyptian clover straw, soybean meal 44\%, yellow corn grain, wheat bran, limestone, and salt to meet the nutrient requirements of lambs according to feeding standards of $N R C$ (1985). The chemical composition of the HFW and the feedstuffs used is presented in Table 1. The three diets were formulated in order to incorporate 0,15 , and $30 \%$ of HFW (on asfed basis) to maintain a nearly similar nutrient density (Table 2). The ingredients of each diet were ground, thoroughly mixed and pressed into pellets to decrease the selection of the feed by the experimental lambs. The chemical analysis of the diets on dry matter (DM) basis is reported in Table 3. 


\section{Experimental parameters:}

\section{Growth performance:}

The growth trial lasted for 8 weeks. Initial and final body weight and body gain were recorded. Feed intake per each animal was daily recorded and finally calculated. Average feed conversion ratio of each animal was then calculated for each group. Average daily gain (ADG) was calculated. Finally, an estimate was made of the feeding cost per kilogram of body weight gain of the three groups.

\section{Digestibility:}

The digestibility trial was conducted at the end of the growth trial and lasted for 5 days collection period. Each lamb was kept fastened by a head collar in a suitable place provided with separate manger and fitted with collecting bag. Daily fecal output was collected, weighed, and recorded, and then $10 \%$ was kept for subsequent analyses. Fecal samples were dried at $55{ }^{\circ} \mathrm{C}$ in a forced-air oven to reach a constant weight, air equilibrated, and then ground to pass 1mm screen (Cyclotec 1093, Foss Sweden) and kept for further analysis. Refused feed samples were collected every $24 \mathrm{~h}$, in individual plastic bags for each animal. Feed offered and feed refused were weighed and sampled (10\%) for each lamb daily. These sub-samples were further mixed into a composite sample by animal, before grinding. Representative samples were stored for analysis. Feed, refusals, and feces were chemically analyzed. 
Eldsokey E. N., Elsayed M. H., Abdelnasser A. B.

Table (1): Chemical analysis of the feedstuffs (on DM basis) used in formulation of the experimental diets

\begin{tabular}{|c|c|c|c|c|c|c|}
\hline NUTRIENTS (\%) & $\begin{array}{c}\text { DRIED } \\
\text { HFW }\end{array}$ & $\begin{array}{l}\text { WHEAT } \\
\text { BRAN }\end{array}$ & $\begin{array}{c}\text { CORN } \\
\text { GRAINS }\end{array}$ & $\begin{array}{l}\text { SOYBEAN } \\
\text { MEAL }\end{array}$ & $\begin{array}{c}\text { ALFALFA } \\
\text { HAY }\end{array}$ & $\begin{array}{c}\text { EGYPTIAN } \\
\text { CLOVER STRAW }\end{array}$ \\
\hline Moisture & 10.51 & 10.9 & 11.9 & 10.9 & 6.82 & 5.55 \\
\hline Dry matter & 89.49 & 89.1 & 88.1 & 89.1 & 93.18 & 94.45 \\
\hline Crude protein & 14.72 & 17.3 & 9.1 & 49.9 & 20 & 7 \\
\hline NDF & 19.95 & 42.5 & 9.5 & 14.9 & 36.49 & 70 \\
\hline $\mathrm{ADF}$ & 11.03 & 15.5 & 3.4 & 10 & 28.26 & 50 \\
\hline NFC & 47.39 & 29.6 & 75.7 & 27 & 28.07 & 8.07 \\
\hline Starch & 32.47 & 22.3 & 73.36 & 2 & 2 & 1.02 \\
\hline Ether extract & 6.96 & 4.3 & 4.2 & 1.6 & 2 & 0.84 \\
\hline Ash & 10.98 & 6.3 & 1.5 & 6.6 & 13.44 & 14.09 \\
\hline Calcium & 1.68 & 0.13 & 0.04 & 0.4 & 1.47 & 0.31 \\
\hline Phosphorus & 0.58 & 1.18 & 0.3 & 0.71 & 0.28 & 0.1 \\
\hline Sodium & 1.17 & 0.04 & 0.02 & 0.04 & 0.1 & 0.12 \\
\hline Total aflatoxins (ppb) & 1.0 & $<2.0$ & $<2.0$ & $<2.0$ & $<2.0$ & $<2.0$ \\
\hline
\end{tabular}

ADF, acid detergent fiber; HFW; household food waste; NDF, neutral detergent fiber; NFC, non fibrous carbohydrate.

Table (2): Ingredients composition of the experimental diets (on as-fed basis)

\begin{tabular}{|c|c|c|c|}
\hline INGREDIENTS (\%) & 0\% HFW & $15 \%$ HFW & $30 \%$ HFW \\
\hline Alfalfa, dried & 15.0 & 16.0 & 16.0 \\
\hline Clover straw, Egyptian & 13.0 & 15.0 & 16.5 \\
\hline Soybean meal $44 \%$ & 11.0 & 11.0 & 11.5 \\
\hline Corn grains, ground & 29.0 & 26.5 & 25.0 \\
\hline Wheat bran & 30.0 & 15.0 & 00 \\
\hline Household food waste & 00 & 15.0 & 30.0 \\
\hline Limestone & 1.5 & 1.2 & 1.0 \\
\hline Common salt & 0.5 & 0.3 & 0.0 \\
\hline Feed cost/ton (LE) & 1545.5 & 1358.78 & 1210,83 \\
\hline
\end{tabular}

Kafrelsheikh Vet. Med. J. Vol. 10 No. 2 (2012) 
Evaluation Of Household Food Waste ...

Table (3): Chemical composition of the diets (on DM basis)

\begin{tabular}{|c|c|c|c|}
\hline NUTRIENTS (\%) & $0 \%$ HFW & $15 \%$ HFW & $30 \%$ HFW \\
\hline Dry matter & 91.36 & 91.27 & 90.45 \\
\hline Crude protein & 16.16 & 16.61 & 17.04 \\
\hline Ether extract & 2.82 & 3.59 & 4.22 \\
\hline Neutral detergent fiber & 31.58 & 30.52 & 26.66 \\
\hline Acid detergent fiber & 18.13 & 18.45 & 18.37 \\
\hline Ash & 8.37 & 8.93 & 10.47 \\
\hline Non fibrous carbohydrate & 41.07 & 40.34 & 41.61 \\
\hline Metabolizable energy (Mcal $/ \mathrm{kg})^{a}$ & 2.52 & 2.55 & 2.58 \\
\hline Calcium & 0.91 & 1.05 & 1.31 \\
\hline Total phosphorus & 0.48 & 0.43 & 0.39 \\
\hline Sodium & 0.59 & 0.69 & 0.88 \\
\hline Total aflatoxins (ppb) & $<1$ & $<1$ & $<1$ \\
\hline
\end{tabular}

${ }^{a}$ Metabolizable energy: calculated using NRC (1985); HFW, household food waste

\section{Carcass characteristics:}

At the end of the experiment, 3 lambs were randomly selected from each group, slaughtered and dressed. Fasted live weight was recorded immediately before slaughtering, and hot carcass weight was recorded after slaughter. Dressing percentage was calculated as the percentages of hot carcass weight/fasted live weight. Liver, kidney and heart were excised and weighed on an electronic scale. Organ weights were expressed as a percentage of body weight and carcass weight. The longissimus dorsi muscle was excised from the right half-carcass between the sixth thoracic vertebra and fifth lumbar vertebra in order to determine meat chemical composition. 


\section{Chemical analyses:}

Sub samples of air dried HFW, wheat bran, corn grain, soybean, alfalfa hay, Egyptian clover straw, complete diets, dried fecal matter and dried meat samples were ground through $1 \mathrm{~mm}$ screen of cyclotec sample mill (1093 Foss, Sweden). The ground samples were analyzed for final DM at $105{ }^{\circ} \mathrm{C}$ for $3 \mathrm{~h}$ in hot air oven (Heraeus, UT 20 model, Germany), crude protein (CP) by kjeldhle technique (Kjeltec system 2100 Foss, Sweden), ether extract (EE) by soxhlet technique (Ankom XT 15 filter bag technology, USA), and ash (Furnace 6000 thermolyne, USA) according to $(\boldsymbol{A O A C}$, 1995). Neutral detergent fiber (NDF) without using sodium sulfite and acid detergent fiber (ADF) were determined according to (Vansoest etal., 1991) with (fibertec M6 1020 Foss, Sweden). The non fibrous carbohydrate concentration (NFC) on $\mathrm{DM}$ basis was calculated using the following equation $\mathrm{NFC} \%=100 \%$ $(\mathrm{NDF} \%+\mathrm{CP} \%+\mathrm{EE} \%+\mathrm{Ash} \%)$. Calcium, phosphorus and sodium were analyzed according to $(\boldsymbol{A O A C}, 2005)$ methods using atomic absorption spectrophotometer (V-630, Jasco, Japan). The total aflatoxin content in the feeds and complete diets was determined according to (AOAC, 1995) method using monoclonal antibody columns for aflatoxins B1 and B2 (VICAM Science Technology, Watertown, MA, USA).

\section{Statistical analysis:}

All the data were analyzed using JMP 10 statistical analysis software package $(S A S, 2012)$. The data were analyzed by ANOVAcomplete randomized, followed by multiple comparisons using Dunnett's LSD procedure. Differences detected at the 0.05 level or less were considered statistically significant. 


\section{RESULTS}

The collection and quantification data revealed that the average quantity of HFW per person daily was $0.344 \mathrm{~kg}$. The final DM of the collected HFW was $26.45 \%$. Chemical composition of HFW is reported in Table 1. HFW was relatively high in CP, EE, NFC, and ash. It was rich in calcium, phosphorus and sodium. It was considered free from total aflatoxins.

Effects of HFW on growth performance, feed intake, feed conversion ratio (FCR) and feeding cost are demonstrated in table 4. There was no significant difference in growth performance between lambs fed on diets containing HFW and those fed on the control diet. Feed intake was nearly similar among all groups. FCR was numerically better for lambs fed on $30 \%$ HFW than the control diet. The cost of production was lower $(P<0.05)$ in lambs fed on $30 \%$ HFW diet as compared to $0 \% \mathrm{HFW}$ fed lambs.

Table (4): Effects of household food waste (HFW) inclusion in diets at different levels on growth performance of the lambs.

\begin{tabular}{|c|c|c|c|}
\hline ITEMS & 0\% HFW & $15 \%$ HFW & $30 \%$ HFW \\
\hline Initial body weight (kg) & $22.55 \pm 0.55$ & $23.23 \pm 0.64$ & $23.16 \pm 0.71$ \\
\hline Final body weight (kg) & $33.01 \pm 0.84$ & $34.0 \pm 1.05$ & $35.39 \pm 1.37$ \\
\hline Body weight Gain (kg) & $10.46 \pm 0.75$ & $10.77 \pm 0.68$ & $12.23 \pm 0.96$ \\
\hline Average daily gain $(\mathrm{kg} /$ day $)$ & $0.188 \pm 0.01$ & $0.192 \pm 0.01$ & $0.218 \pm 0.02$ \\
\hline Feed consumed (kg/day) & $1.13 \pm 0.03$ & $1.15 \pm 0.03$ & $1.18 \pm 0.04$ \\
\hline FCR & $6.01 \pm 0.26$ & $5.99 \pm 0.32$ & $5.41 \pm 0.26$ \\
\hline Cost/kg gain (LE) & $9.29^{\mathrm{a}} \pm 0.4$ & $8.14^{\mathrm{a}} \pm 0.44$ & $6.55^{\mathrm{b}} \pm 0.31$ \\
\hline
\end{tabular}

Means \pm standard error in the same row with different letters (a and $b)$ are significantly different $(\mathrm{P}<0.05)$.

$\overline{\text { Kafrelsheikh Vet. Med. J. Vol. } 10 \text { No. } 2 \text { (2012) }}$ 
Digestion coefficients of DM, CP, EE, NDF, ADF and NFC of the control diet and diets containing HFW are summarized in Table 5. Ether extract digestibility was higher with lambs fed diets containing HFW $(15 \%$ and $30 \%)$ than those on the control diet.

Table (5): Effects of household food waste (HFW) inclusion in lamb diets at different levels on nutrients digestibility.

\begin{tabular}{|l||c||c||c||}
\hline \multicolumn{1}{|c||}{ Nutrients (\%) } & $\mathbf{0 \%}$ HFW & $\mathbf{1 5} \% \mathbf{H F W}$ & $\mathbf{3 0} \% \mathbf{H F W}$ \\
\hline \hline Dry matter & $69.33 \pm 1.2$ & $70.84 \pm 1.69$ & $71.24 \pm 2.8$ \\
\hline Crude protein & $73.5 \pm 2.1$ & $73.0 \pm 1.73$ & $71.5 \pm 2.87$ \\
\hline Ether extract & $51.68^{\mathrm{b}} \pm 3.44$ & $73.95^{\mathrm{a}} \pm 3.01$ & $74.11^{\mathrm{a}} \pm 1.24$ \\
\hline Neutral detergent fiber & $47.50 \pm 2.22$ & $51.75 \pm 3.15$ & $56.0 \pm 4.81$ \\
\hline Acid detergent fiber & $27.75 \pm 2.81$ & $31.75 \pm 2.93$ & $30.5 \pm 2.88$ \\
\hline Non fibrous carbohydrate & $87.5 \pm 1.04$ & $87.25 \pm 0.63$ & $86.25 \pm 1.3$ \\
\hline
\end{tabular}

Means \pm Standard error in the same row with different letters (a and b) superscripts are significantly different $(\mathrm{P}<0.05)$.

There was no significant difference among various groups in mean digestibility coefficients of DM, CP, NDF, ADF and NFC.

Results concerning carcass characteristics of lambs fed the control diet and diets containing HFW are showed in Table 6. Although there was no statistical difference among dietary treatments, lambs fed on $30 \%$ HFW diet were numerically higher in fasting weight, carcass weight, dressing percentage. 
Evaluation Of Household Food Waste ...

Table (6): Effects of household food waste (HFW) inclusion in lamb diets at different levels on carcass characteristics

\begin{tabular}{|c|c|c|c|}
\hline Items & $0 \%$ HFW & $15 \%$ HFW & $30 \%$ HFW \\
\hline Fasting weight $(\mathrm{Kg})$ & $34.03 \pm 1.29$ & $34.03 \pm 2.75$ & $35.22 \pm 0.99$ \\
\hline Carcass weight (kg) & $18.03 \pm 0.73$ & $18.34 \pm 1.33$ & $19.62 \pm 0.77$ \\
\hline Dressing percentage & $52.98 \pm 0.37$ & $53.89 \pm 1.52$ & $55.71 \pm 1.19$ \\
\hline \multicolumn{4}{|l|}{ Liver } \\
\hline$\%$ of body weight & $1.81 \pm 0.13$ & $1.84 \pm 0.15$ & $1.81 \pm 0.08$ \\
\hline$\%$ of carcass weight & $3.29 \pm 0.31$ & $3.37 \pm 0.18$ & $3.26 \pm 0.09$ \\
\hline \multicolumn{4}{|l|}{ Kidneys } \\
\hline$\%$ of body weight & $0.48 \pm 0.01$ & $0.48 \pm 0.08$ & $0.51 \pm 0.06$ \\
\hline$\%$ of carcass weight & $0.87 \pm 0.05$ & $0.89 \pm 0.01$ & $0.91 \pm 0.06$ \\
\hline \multicolumn{4}{|l|}{ Heart } \\
\hline$\%$ of body weight & $0.32 \pm 0.01$ & $0.35 \pm 0.03$ & $0.31 \pm 0.01$ \\
\hline$\%$ of carcass weight & $0.58 \pm 0.02$ & $0.65 \pm 0.06$ & $0.56 \pm 0.02$ \\
\hline
\end{tabular}

Means \pm standard error in the same row are not significant $(\mathrm{P}>0.05)$.

Chemical composition of the meat samples are shown in Table 7. Chemical analysis did not evidence significant differences in moisture, protein, ash and fat content, although the 15\% HDFW group showed a slightly higher fat content.

Table (7): Effects of HFW inclusion in lamb diets on carcass chemical composition (on fresh basis)

\begin{tabular}{|c|c|c|c|}
\hline Item & $0 \%$ HFW & $15 \%$ HFW & $30 \%$ HFW \\
\hline Moisture & $72.07 \pm 1.47$ & $69.97 \pm 1.25$ & $71.37 \pm 0.83$ \\
\hline Dry matter & $27.93 \pm 1.47$ & $30.03 \pm 1.25$ & $28.63 \pm 0.83$ \\
\hline Crude protein & $21.64 \pm 0.61$ & $22.04 \pm 0.47$ & $22.7 \pm 0.63$ \\
\hline Ether extract & $5.12 \pm 0.87$ & $6.84 \pm 0.76$ & $4.67 \pm 0.23$ \\
\hline Ash & $1.16 \pm 0.04$ & $1.16 \pm 0.02$ & $1.26 \pm 0.02$ \\
\hline
\end{tabular}

Means \pm standard error in the same row are not significant $(\mathrm{P}>0.05)$

$\overline{\text { Kafrelsheikh Vet. Med. J. Vol. } 10 \text { No. } 2 \text { (2012) }}$ 


\section{DISCUSSION}

The average quantity of HFW per person daily was nearly similar to the result of Rutgers University ( $0.330 \mathrm{~kg}$ per person daily) (National Recycling Coalition, 2008). The final DM of the collected HFW of this study was considered high. Ben (2001) mentioned that final output from food waste processing plant is $20 \%$ of the total input.

The data of the present study indicated that the nutrients composition of the HFW were high in CP, fat and minerals and this is attributed to physical components of HFW: a lot amount of pea, beans, meat, fish, fruits, vegetables, bones, rice, breads, egg shell, boiled oils and animal fat wastes. Similarly, available food by-products in Japan usually have high energy and/or protein contents, which can provide competitive alternatives to more traditional energy or protein sources (Westendorf, 2000).

The positive effects of HFW on growth performance may be attributed to its contents of high valuable nutrients and of high digestibility as shown in Tables 1 and 5 respectively. Feeding HFW to Lambs was characterized by similar feed consumption when compared to the control diet; this indicated that palatability was good. Summers et al., (1980) mentioned that sheep readily adapted to a diet containing $35 \%$ of $\mathrm{DM}$ as FW, their daily DM intake being $4.5 \%$ of body weight; this suggested that palatability was no problem. Using $30 \%$ processed FW in diets for chicken in conjunction with other essential ingredients achieved adequate results for body weight, feed consumption and feed conversion (Normand, 1997). 
The income on diet containing 30\% HFW was higher than the control one and this was due to the lower cost of HFW than the wheat bran. The study approved that it is financially feasible and it is economically to use HFW in lamb diets. Similarly, Ben (2001) concluded that it is economically to use processed FW products in duck rations.

Fat digestibility was higher with lambs fed diets containing $15 \%$ and $30 \%$ HFW than those on the control diet. This might be due to the different sources of fat in diets containing HFW. Summer et al., (1980) indicated that digestibility values of 76,68 and 73 were calculated for $\mathrm{DM}, \mathrm{CP}$ and EE fractions of FW, indicating that the material had a high nutritive value for sheep.

There was a positive relationship between fasting weight, carcass weight and dressing percentage. There were no abnormalities in the weights of liver, kidneys and heart in all groups. This emphasized by chemical analysis of HFW and diets which revealed that they were free from aflatoxins. There was no significant difference in carcass chemical composition among different groups because the diets were nearly similar in energy and protein density (Table 3). In contrast, Normand (1997) concluded that carcass fat was increased in ducks due to the high fat content of certain FW but this could be readily avoided by attention to dietary calorie: protein ratios in feed formulation.

\section{ACKNOWLEDGMENTS}

The authors wish to thank the Research Support Fund of Kafrelsheikh University for the financial support of this project. 


\section{CONCLUSION}

Results of this study indicated that HFW is free from total aflatoxins especially of efficiently collected and perfectly dried. It is relatively high in protein, fat, non-fibrous carbohydrate, and minerals. Inclusion of HFW at levels up to $30 \%$ still having positive effects on growth, digestibility and carcass characteristics. It has no negative effects on carcass characteristics or meat chemical composition. Generally, HFW could be successfully used as a valuable feedstuff and recycling it as animal feed is profitable. Still, further studies on HFW processing technology and feeding system with other animal species are needed.

\section{REFERENCES}

- Association of Official Analytical Chemists (AOAC), 2005. Official Method of Analysis, 18th ed. AOAC Int. Gaithersburg, MD.

- Association of Official Analytical Chemists (AOAC), 1995. Official Methods of Analysis, 16th ed. AOAC, Washington, DC, USA.

- Ben, A.A., 2001. Economic feasibility of processing food waste and incorporating products in least cost duck feeds. M.Sc. Thesis, University of Mc Gill, Montreal Quebec, Canada.

- Boucque, Ch.V., Fimes, L.O., 1988. Vegetable by-products of agroindustrial origin. Livestock production science. 19, 97-135.

- Cao, Y., Takahashi, T., Horiguchi, K., 2009. Effects of addition of food by-products on the fermentation quality of a total mixed ration with whole crop rice and its digestibility, performance, and rumen fermentation in sheep. Anim. Feed Sci. Technol. 151, 1-11. 
- Hall, K.D., Guo, J., Dore, M., Chow, C.C., 2009. The progressive increase of food waste in America and its environmental impact. Plos One, 4(11), e7940.

- Kawashima, T., 2004. The use of food waste as a protein source for animal feed - current status and technological development in Japan. In Protein sources for the animal feed industry. FAO Expert Consultation and Workshop, Bangkok, Thailand, 29 April- 3 May 2002, pp. 303-309.

- National Recycling Coalition, 2008. Recycle Mania 2008 spurs college campuses to score big for the "Green Team". Retrieved March. 10, 2008, from http://www.recyclemania.org/.

- Normand, L., 1997. Recycling of industrial food wastes into feed for Pekin duck meat production. M.Sc. Thesis, University of Mc Gill, Quebec, Canada.

- NRC, 1985. Nutrient Requirement of Sheep and Goats, 6th ed. National Academy of Sciences, Washington, DC, USA. SAS, 2012. Using JMP 10. Cary, NC, USA.

- Summers, J.D., Macleod, G.K., Warner, W.C., 1980. Chemical composition of culinary wastes and their potential as a feed for ruminants. Animal Feed Science and Technology. 5, 205-214.

- Van Soest, P.J., Robertson, J.B., Lewis, B.A., 1991. Methods for dietary fiber, neutral detergent fiber, and non starch polysaccharides in relation to animal nutrition. J. Dairy Sci. 74, 3583- 3597.

- Westendorf, M.L., 2000. Food waste as animal feed: an introduction. In: Westendorf, M.L. (Ed.), Food Waste to Animal Feed. Iowa State University Press, Ames, IA, pp. 3-15. 